\title{
Paměf' a prostor: Reprezentační strategie společenstva vzpomínání v postindustriálním městě
}

\section{Space of Memory and Space of Places: Representational Strategies of a Community of Commemoration in a Post-Industrial City}

\author{
Petra L. Burzová, llona Dvořáková, Ondřej Hejnal, \\ Michal Rưžička, Laco Toušek
}

\begin{abstract}
This article focuses on the former working-class neighborhood of Karlov, built at the beginning of the $20^{\text {th }}$ century by Skoda Works in Pilsen. We study the now non-existing place in the context of the transforming urban space of an industrial metropolis, and its relation to its collective (witness) representations. Based on data from interviews with living contemporaries, participant observation during commemorative meetings and archival research, we analyze the negotiated changes in the representational strategies of "Karlovers." In the article we study two forms of Karlov: commemorative Karlov, as it is remembered and produced by the former inhabitants of Karlov during their regular meetings, when they retroactively construct Karlov as a meaningful place and an ideal for life in an urban environment. Then we attempt to explain why this commemorative Karlov resists being identified with the remaining Karlov, that is, with the physical and architectonical remains of the commemorated place.
\end{abstract}

KEY WORDS Collective memory, construction of identities, memory of place, urban anthropology, Karlov, Pilsen, postindustrialism

\section{Úvod}

V Plzni, podobně jako v dalších postindustriálních městech, se v posledních desetiletích objevují nejrůznější iniciativy usilující, v souladu s ideou „postmoderního urbanismu“ (Crinson 2005: xi), o rekonverzi objektů moderní průmyslové architektury. ${ }^{2}$ Tyto budovy

Sociálni studia. Katedra sociologie FSS MU, 4/2013. S. 107-126. ISSN 1214-813X.

1 Stat' je dílčím výstupem z projektu Sídelni a krajinný prostor jako odraz kulturního dědictví a paměti národa (č. DF12P01OVV008), jehož nositelem je Katedra antropologie FF ZČU. Děkujeme oběma anonymním recenzentům za podnětné připomínky.

2 Rekonverze průmyslových památek bývá v České republice považována za pozitivní zásah do městského prostoru a kriticky se upozorňuje spíše na pomalé tempo (re)konverzí, údajně ohrožující budoucnost mnoha chátrajících objektů, respektive tzv. brownfields. Odborníci z řady disciplín se v různé míře shodují na předpokladu, že průmyslová architektura má jistou hodnotu, jejíž ochrana je celospolečenským zájmem (srov. napřr. Fragner 2004; Temelová a Novák 2007; Hájek 2009). 
nabývají nových hodnot: jsou nositeli historického dědictví, arénami pro kulturní vyžití, případně nabízejí materiální rámec pro oživení dávno ztraceného veřejného prostoru a komunitního génia loci (Gibas 2008). ${ }^{3}$ Mladý architekt a urbanista, jeden ze spoluzakladatelů jedné takové iniciativy nazvané Škoda Plzně v nedávném textu o starých plzeňských továrních budovách píše:

Při citlivé přestavbě, jež jim vdechne nový život, by obohatily město dalším unikátem. Dalo by se tedy říci, že město stojí před rozhodnutím století. Bud' se s vidinou rychlejších zisků a větších kapacit začnou areály jeden po druhém demolovat a místo nich vzniknou uniformní čtvrti notoricky známé ze současného developmentu. Nebo si investoři uvědomí jejich skutečnou hodnotu a podaří se industriální bohatství uchránit, rekonstruovat a dostavět. Město by tím poskočilo mílovými kroky směrem $\mathrm{k}$ výjimečnosti a prosperitě, a je v jeho kompetenci držet nad továrnami ochrannou ruku. (Sivák 2012)

Průmyslová architektura, která v době industrializace nevratně změnila socioprostorovou strukturu měst, se dnes stává předmětem historizace a nostalgizace. Tak bývá urbánní průmyslová krajina, vedle středověkých kostelních věží, reprezentována jako hodnotný zdroj urbánní paměti a identity (Crinson a Tyrer 2005: 50). V Plzni se taková estetizující nostalgie stala jádrem podpory projektů rekonverzí, které zavádějí do průmyslových objektů nové využití jako prostředek záchrany průmyslové městské paměti. ${ }^{4} \mathrm{~K}$ průmyslovému dědictví městského prostoru v Plzni se hlásí i projekt Evropské hlavní město kultury (EHMK). Titul EHMK pro rok 2015 vydobyla Plzeň v souboji s dalším průmyslovým městem Ostravou, když byla mezi nejvýznamnějšími počiny prezentována právě rekonverze bývalého měšt’anského pivovaru Světovar na kulturní fabriku (viz níže). Nostalgizace architektury a městské krajiny se pak projevuje, mimo jiné, také v produkci populární faktografické literatury zachycující historickou podobu a transformaci konkrétních míst nebo již zaniklé objekty a lokality. ${ }^{5}$ Hojně navštěvované také bývají architektonicko-urbanistické procházky Plzní organizované sdružením Škoda Plzně a nově také projektem EHMK 2015 nebo veřejné přednášky zabývající se historií plzeňského průmyslu.

Ne všem stavbám z minulosti se daří stávat se památníkem pro budoucí generace. Jedním z takových míst se pravděpodobně stane i plzeňský Karlov, bývalá dělnická kolonie postavená na přelomu první a druhé dekády 20. století plzeňskou Škodovkou za účelem ubytování rostoucího počtu dělníků v průmyslovém městě. Karlov začal svoji městskou „kariéru“ jako výstavní místo kvalitního dělnického ubytování, aby od druhé světové války, kdy byl výrazně poničen

3 Kolejka a Klimánek (2012) mezi definiční znaky postindustriální krajiny zahrnují, mimo jiné, také formování génia loci některých míst.

4 Část továrny Papírna Slovany si například pronajímá provozovatel motokárové dráhy; další prostory pak bývají využívány pro různé kulturní akce typu výstav. Bývalé nádraží na Jižním předměstí, známé dnes jako „Jižák“, také slouží jako místo pro pořádání kulturních aktivit. Několik budov Škodových závodů je využíváno vědeckým centrem Techmania, jehož cílem je popularizovat vědu a techniku. Podobně pak pivovar Plzeňský Prazdroj vyhradil několik svých objektů pro potřeby turistického ruchu.

$5 \quad$ Např́klad Zmizelá Plzeň nebo řada fotografických publikací z nakladatelství Starý most. 
během bombardování Škodovky, na svém bývalém lesku postupně ztrácel. Spolu s tím, jak se od 60. let 20. století začalo s výstavbou moderních panelových sídlišst' na kraji Plzně, se bývalé kvalitní bydlení, nyní v neopravené zbombardované čtvrti, postupně měnilo v polozapomenuté místo, aby byl Karlov nakonec v roce 1986 definitivně srovnán se zemí, a mohl tak uvolnit místo expandujícímu průmyslu (podrobněji srov. např. Burzová a kol. 2013).

$\mathrm{Na}$ tváři města po Karlovu zůstalo jenom několik reziduálních materiálních stop. ${ }^{6}$ Zůstávají stát poslední záchytná místa ve fyzickém prostoru města. Žijí a vzpomínají poslední pamětníci. Karlov dnes existuje coby smysluplné místo právě díky vzpomínkové reprezentaci jeho někdejších obyvatel, utvářejících místně-specifické „společenstvo paměti“. To by samo o sobě nebylo nikterak výjimečné. ${ }^{7}$ Co však lze považovat za zajímavý fenomén, je skutečnost, že se existující „společenstvo paměti“ (bývalí obyvatelé Karlova, tzv. „Karlováci“, kteří se pravidelně minimálně dvakrát do roka scházejí a kolektivně na Karlov vzpomínají) brání spojovat jejich vzpomínkový Karlov s Karlovem reziduálním (tj. s tím, co po Karlovu v dnešní době v městském prostoru zbývá). Jako kdyby v jejich očích, respektive paměti, existovala určitá „ontologická diskontinuita“ mezi dvěma Karlovy: mezi Karlovem takovým, jaký je v jejich kolektivní paměti, a Karlovem reziduálním, tj. dnešním místem, kde Karlov v minulosti stával.

Cílem našeho článku je tuto „ontologickou diskontinuitu“ mezi reziduálním a vzpomínkovým Karlovem prozkoumat. Na pozadí postindustriální reorganizace městského prostoru proto pátráme po vnitřní logice reprezentačních strategií společenstva vzpomínání založených na distinkci mezi prostorem paměti a prostorem míst. Po seznámení s konceptuálními a teoretickými perspektivami, ze kterých $\mathrm{v}$ textu vycházíme, představíme reprezentační strategie Karlováků, pomocí kterých prosazují Karlov jako unikátní a kulturně relevantní symbolické misto paměti.

Teprve poté, na pozadí procesů historizace a nostalgizace městského prostoru a průmyslové architektury, se pokusíme porozumět tomu, proč se dnešní společenstvo vzpomínání vzdává reziduálního Karlova jako aktuálního referenčního rámce pro praxi vzpomínání (a zapomínání) na Karlov.

V textu vycházíme z historického, etnografického a archivního výzkumu, pomocí kterého jsme chtěli lépe porozumět Karlovu jako specifickému místu, které se vyvíjelo a transformovalo tak, jak se vyvíjel a transformoval vnější politicko-ekonomický kontext. Karlov

6 Kromě dvou objektů - bývalé sokolovny a Lidového domu - je lze identifikovat mimo jiné v toponymech. Na mapách se dodnes zachovalo místní označení Karlov a někdy se o někdejší lokalitě referuje jako o bývalé městské části, zachovaly se názvy ulic Ke Karlovu, Na Pomezí, zastávky autobusu Karlov, Sedlárna nebo Lodní nazvané podle někdejší první ulice kolonie. Místní název nese i několik provozoven v okolí, mimo jiné prodejna automobilů, ubytovna nebo skladovací hala. Kontinuitu s někdejší kolonií lze pravděpodobně nalézt v názvu tělocvičné jednoty TJ Karlov sídlící v sokolovně, avšak na základě rozhovorů s členy oddílu tato vazba již pro většinu nenese jiný než topografický význam.

7 V rozhovorech s pamětníky jsme byli opakovaně odkazováni na „konkurenční“ místně specifické srazy v Plzni, organizátoři vzájemně sledují pokroky těch, kteří „,to dělají na profesionální úrovni“, a není dokonce výjimkou, že se jim členství překrývá s členstvím v jiných místně-specifických společenstvích paměti. 
pro nás byl místem, jehož vznik, rozvoj a zánik „kopíroval“ způsoby, jakými se v širším měřítku uspořádával vztah mezi prostorem a společností, která jej tvoří, přetváří a obývá. Čerpali jsme z datového souboru o několika položkách. Nejvýznamnějším zdrojem dat nám bylo 26 transkripcí a poznámek z polostrukturovaných a nestrukturovaných rozhovorů s pamětníky - někdejšími obyvateli Karlova, kteří se účastní společných komemorativních událostí, a lze je tak považovat za aktéry, kteří spolu(re)produkují specifický diskurz společenstva vzpomínání na Karlov. Druhým zdrojem dat nám pak byly poznámky z participativního pozorování vzpomínkových a pamětnických událostí, počínaje pravidelnými organizovanými srazy, veřejnými debatami a přednáškami, konče komentovanými prohlídkami Karlova a dalších městských částí Plzně, které organizovali samotní pamětníci, respektive specializovaná sdružení architektů a urbanistů (například Škoda Plzně) nebo pamět'ové instituce (například Archiv města Plzně). Abychom lépe porozuměli vztahu někdejších obyvatel $\mathrm{k}$ dané lokalitě, rozhodli jsme se do zkoumané oblasti intervenovat. Společně s organizátory srazů jsme uspořádali jedno vzpomínkové setkání přímo na Karlově, pamětníkům jsme opakovaně nabídli zpřístupnění zavřeného Lidového domu a také jsme na podzim roku 2013 uspořádali o Karlově výstavu. Třetím zdrojem dat užitým k analýze procesu historizace architektury v Plzni je obsah regionálního tisku, tiskových zpráv a článků dostupných na webových stránkách institucí a sdružení, informačních materiálů města Plzně k projektu Evropské hlavní město kultury a další mediální výstupy. Analýzu jsme prováděli s využitím specializovaného softwaru na kvalitativní zpracování dat MAXQDA. ${ }^{8}$

\section{Paměf', místo, nostalgie}

Podoba zítřejší městské krajiny bude do velké míry ovlivněna úspěchem dnešní mobilizace nostalgie. Zdá se, že zájem o dosud zanedbávané relikty průmyslové minulosti se ze všech stran neustále zvyšuje. ${ }^{9}$ Petr Gibas s odkazem na A. Huyssena (2008: 111) ukazuje, že vizuální reprezentace průmyslových objektů je dnes do velké míry nostalgická: „Jsme nostalgičtí za ruinami modernity, protože v sobě stále nesou příslib, který z naší vlastní přítomnosti vymizel: př́slib alternativní budoucnosti." Podobně jako soudobá vlna historizace architektury a nostalgie vůči chátrající městské průmyslové krajině, také neutichající zájem o minulost lze považovat za signifikantní projev postmoderní transformace (Olick a kol. 2011: 399; Nora 2002). Radim Marada a Csaba Szaló (2010) poukazují na existenci vztahu mezi zvyšováním zájmu o vzpomínání a relativně větší svobodou, kterou dnešní aktéři vzpomínání disponují, v rámci procesů vypravěčského „uvolnění“ a „emancipace paměti“. Naopak Pierre Nora (1998) dává sociální potřebu vytváření míst paměti spojenou s jejich performancí v rámci různých vzpomínkových slavností do souvislosti s postmoderním zánikem „přirozených míst“.

Způsob, jakým dnes uvažujeme o sociálně utvářené paměti, zásadním způsobem ovlivnil Maurice Halbwachs (2009; srov. též Truc 2012; Olick a kol. 2011; Rose-Redwood a kol.

$8 \quad$ Pro podrobnější představení metodologie našeho výzkumu dělnické kolonie Karlov viz Burzová a kol. (2013).

9 Za zmínku stojí například rozsáhlé aktivity Výzkumného centra průmyslového dědictví FA ČVUT v Praze. 
2008). Halbwachs kromě sociální dimenze paměti docenil také prostorové zakotvení kolektivního vzpomínání (2009: 110, 187-188, 200, 226). Podle Halbwachse je pamět’ vždy spojena s prostorově zakotvenou kolektivní zkušeností a předpokladem každé kolektivní paměti je přetrvávání materiálního prostředí, ke kterému se upíná (2009: 200). K tomuto teoretickému předpokladu se vrátíme v závěru našeho textu, vyvstává z něho pro nás jednoznačná otázka: Jak je možné, že karlovská pamět' trvá, ačkoliv skupina již neupírá svou pozornost k fyzickému prostorovému uspořádání a materiálním stopám po Karlově? Máme za to, že Halbwachsovo pojednání o prostoru je v této otázce (kolektivní pamět’ existuje pouze potud, pokud existuje materiální prostor, jenž je jejím referenčním rámcem) kontradiktorní.

Podobně jako Halbwachs, Nora (1998) upozorňuje na rozdíl mezi pamětí a historií. Pamět’ je vždy zakotvená, intencionální a specifická, a to na rozdíl od historie, která je vždy „neúplnou rekonstrukcí“ a reprezentací minulosti. Vzpomínání vždy znamená ztrátu, kterou dle Nory dnes kompenzují místa paméti, jakými jsou knihy, komemorativní události, budovy nebo památníky, na kterých jsou místa paměti kolektivně vytvářena. Tato místa se nalézají mezi pamětí a historií a vždy v sobě spojují symbolické, materiální a funkční elementy. Jakmile se však tato místa stanou ,předmětem kontemplace, také se nám odcizí, stanou se předměty zkoumání a re-prezentace historie“" (Crinson a Tyrer 2005: 50). ${ }^{10}$ Dle Olicka (1999) znamená zkoumání kolektivní paměti zkoumání několika vrstev jevů: sociálně rámovaných pamětí, kolektivních komemorativních (sdílených) reprezentací a mnemotechnických nástrojů. Rovněž nesmíme opomenout společenstva paměti a význam zúčastněného vzpomínání, protože kolektivní pamět’ v nich hraje roli „konstitutivního narativa“.

Mistem rozumíme jakýkoliv prostor, který je smysluplný v určitém mocenském usporádání a který je zároveň způsobem, jakým nahlížíme svět, poznáváme ho a rozumíme mu (Creswell 2004). Místo není nikdy zcela stabilní, nebot' podléhá vlivům řady vnějších politických a ekonomických faktorů, které městský prostor průběžně a nevyhnutelně transformují (Harvey 1996). Jednou z možností, jak těmto dalekosáhlým změnám vzdorovat, je konstrukce „pomyslných míst“ (Harvey 1996: 304-306). Hledání autentického smyslu místa je další z možných forem rezistence, do které patří i lokalizace „kolektivní paměti“ do místa, kde „,se identita vytváŕí konstrukcí vzpomínek spojujících skupinu lidí s minulostíc a stává se můstkem spojujícím minulost s přítomností (tamtéž). Vztah mezi prostorem a vzpomínáním není náhodný a výběr míst, která se stanou nebo zůstanou místy paměti, bývá výsledkem vědomých komemorativních rozhodnutí. Tato rozhodnutí bytostně závisí na vnějších socioprostorových podmínkách (Rose-Redwood a kol. 2008). Pokud lze lokalizaci kolektivní paměti do míst paměti chápat jako snahu o prosazení jistého typu sdílených reprezentací, a tudíž i jako snahu o reprodukci jistého sociálního řádu, je zřejmé, že místa paměti jsou scénou, na které se sdílené reprezentace vyjednávají. Je proto důležité sledovat, které sdílené reprezentace se v určitém kontextu prosadí a která kolektivní pamět' naopak zůstane „,vymístěná“. Americký filozof a fenomenolog Edward Casey (1987) v otázce vzpomínání klade podobně jako Olick důraz na participaci v komemorativních aktech. V této souvislosti identifikuje jako klíčový

10 Pierre Nora uchopuje místa paměti poměrně široce. $\mathrm{V}$ tomto textu budeme tento termín užívat v užším pojetí jako fyzické nebo vzpomínkové prostory, ke kterým se váže (místně) specifická kolektivní pamět'. 
prvek vzpomínání místní pamět', kterou chápe jako dispozici vdechující současnosti minulý život, naplňující současnost sociální pamětí (Casey 2000: 181-215).

Na úrovni města pak lze mluvit o paméti urbánní (Crinson 2005). Tento koncept odkazuje k postmoderní transformaci města, které jako konstelace městské krajiny, komplexu objektů a dalších reliktů moderní minulosti umožňuje zkušenost „prrítomnosti nepřítomného“ (presence of absence) - zažívání ztráty minulého vyvolávající nostalgii. Zkoumání urbánní paměti, paměti míst a sdílených reprezentací nám umožňuje porozumět způsobům, jak si různé skupiny obyvatel města představují městský život (Rose-Redwood a kol. 2008), ale také toho, do jaké míry jim je umožněno jejich představy autenticky uplatňovat.

\section{Vzpomínkový Karlov: „Kam jsme vlezli, tam jsme byli doma“}

V této části nechceme představit historizující popis Karlova, protože tak činíme na jiném místě (Burzová a kol. 2013). Místo toho se pokusíme na základě rozhovorů s pamětníky rekonstruovat sdílenou reprezentaci Karlova, která slouží jako konstitutivní narativ společenstva paměti „Karlovákư“, tedy účastníků pravidelných srazů bývalých obyvatel zaniklé dělnické kolonie (dvou takových setkání jsme se aktivně spolu-účastnili, s cílem lépe porozumět způsobům konstrukce kolektivní identity „Karlovákư“, jakož i jejich vztahu k místům, ke kterým ve svých naracích referují). Následující narativ je výsledkem analýzy aktérských popisů toho, ,jaký vlastně Karlov byl“":

Dělnická kolonie Karlov byla krásná čtvrt zbudovaná Škodovými závody v roce 1911 pro své vyučené dělníky. Bydlelo se tam dobře, dělnická čtvrt' - ačkoliv postavená v izolaci od města na okraji obrovské struktury Škodovky - měla téměř venkovský ráz, protože ke každému bytu náležela předzahrádka, na ulicích byly vysázeny lípy a kaštany, v blízkosti byl parčík, pole a lesy Českého údolí. Kousek od Karlova bylo letiště, kde se cvičili letci a které sehrálo významnou roli ve druhé světové válce. Karlov byl místem, které poskytovalo dětem volnost a dostatek možností k hraní. I když byl v těsné blízkosti Škodovky, špína, prach a hluk kompenzovaly blízká pole, př́roda a slabý automobilový provoz.

Na Karlově se nacházelo veškeré zázemí - kulturní, sportovní, zásobovací - dostačující pro naplnění každodenních potřeb obyvatel, jinak řečeno, „bylo tam všechno“. Bylo tam mimo jiné také fotbalové hřiště, hřiště pro děti, Sokol a Dělnická tělovýchovná jednota. V zimě si děti vyráběly ledovou plochu pro hokej a krasobruslení, příčné ulice využívaly pro sáňkování. Bylo pravidlem, že všechny děti chodily do cvičení.

Ještě před válkou měl Karlov i vlastní krásnou školu, ,plzeňskou Sorbonnu“ - nejkrásnější školu v Plzni, kterou zničily americké nálety koncem války. Tyto nálety zničily téměř celou Škodovku a tři karlovské ulice. Důvodem byl fakt, že Škodovka v tom čase sloužila zájmům hitlerovského Německa. Karlov byl zároveň místem, kde se narodily slavné osobnosti, letci druhé světové války, fotbalisté nebo slavný fotograf Vilém Heckel.

Samotné domy vystavěla slavná plzeňská firma Muller \& Kapsa. ${ }^{11} \mathrm{Na}$ svou dobu se jednalo o kvalitní bydlení; na stavbu firma použila kvalitní cihly považované za nerozbitné,

11 Tato firma vystavěla i zmiňovaný Světovar a několik objekti̊ v centru města, což její současný význam a atraktivitu jejích staveb symbolicky zvyšuje. 
kvalitní dřevěná prkna, která dodnes slouží těm, kdo si je během demolice rozebrali. I když vnitřní dispozice bytů byla ve srovnání s dneškem stísněná, tato stísněnost vedla ke zvýšené tolerantnosti a skromnosti. Vůbec, mezilidské vztahy byly na Karlově ideální. Obyvatelé Karlova jsou dodnes patrioti, drží při sobě a rádi se scházejí a společně vzpomínají: „Zkrátka ten, kdo tam žil, na to v životě nezapomene.“

Obrázek 1: Jedna z fotografií, která bývá použita v reprezentativních článcích o Karlovu a slouží jako elicitační a pamětová pomůcka na pamětnických srazech, zobrazuje Karlov krátce po jeho výstavbě $\mathrm{v}$ roce 1911

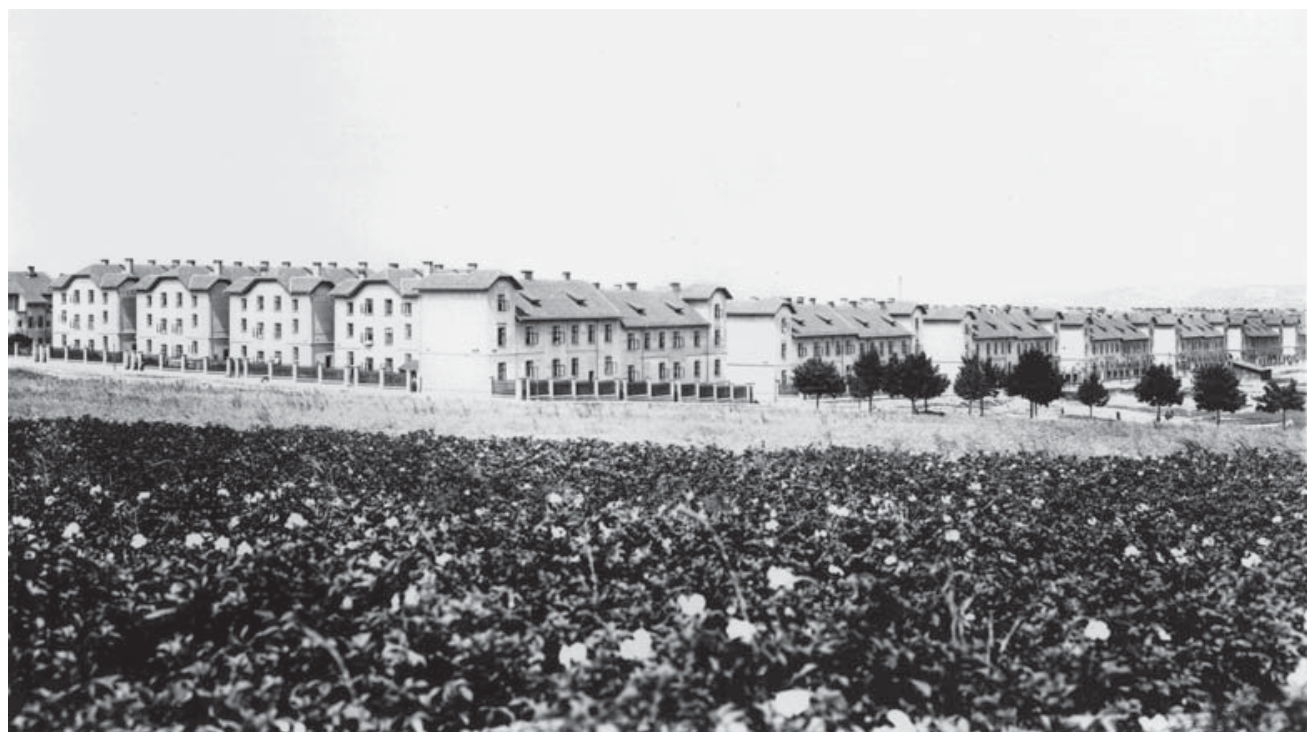

Zdroj: Archiv informátorů

Když jsme se ptali našich informátorů, co „bylo na Karlově nejlepší“, jako první většnou vyvstala kvalita mezilidských vztahů, kterou velmi často kladli do kontrastu s dnešní vysoce individualizovanou městskou společností. Vzpomíná se na dětství, kdy se všechny děti mezi sebou znaly a hrály si spolu, dále na nejrůznější, zejména sportovní, organizace a spolky, ve kterých obyvatelé Karlova v mládí trávili volný čas. V rozhovorech většinou zazní i dovětek o dnešním trávení volného času, který pamětníci shledávají u dětí a mladých lidí jako nevyužitý, nebo dokonce promarněný.

No, tam ty lidi byli takový družní, scházeli se tam, vzali si židle, sedli si do uličky a tam se spolu bavili. V dnešní době kdopak se v baráku sejde. Akorát Cikáni na vinicích, těch je tam všude plno, ty se tam srocují, ale normální lidi aby se takhle sešli, to ne. (H. R.)

Důležitým aspektem vzpomínkového sociálního pořádku, který informátoři vyzdvihují, byla výchova a účinná sociální kontrola v kontrastu s dnešním pocitem nerespektování toho, co považují za pravidla slušného chování: 
Mimo jiné, neustále, když jsem vylezl z domu, ženské sedávaly v uličkách... to bylo jen samé „dobrý den, dobrý den, nazdar, dobrý den“, protože stačilo přijít domů, nakupovat... a dostal jsem pár facek od mámy, že jsem nepozdravil paní Husákovou, když jsem řekl „já jí přehlídl“, tak ,pic pic“, už jsem ji měl. Tam se muselo všude zdravit, mami šla na nákup a tam hned na ni „no Bohuno, ten tvůj kluk neumí zdravit“ a já dostal přes držku, tak to fungovalo. To nebylo jako ted’, když jste třeba v ordinaci nebo kdekoli a říkáte si ,proboha, on je němý“, on tam vejde jako do chlíva, nepozdraví. To je normální v tutej době, pravidelně, nesčíslněkrát za den, kam jdu, tam všichni jako němí. Mladý lidi, ženské ve vašich letech neumí vůbec pozdravit, za to bych dostal hned přes držku. (J. Z.)

Jelikož je participace na vzpomínání také aktem reprodukce společenstva, je důležité sledovat, kdo se srazů, které plní roli vzpomínkových obřadů a slavností místa paměti, může legitimně účastnit a jak se na jednotlivé účastníky nahlíží. Když se jako pozorovatelé srazů účastníme, jsme často upozorňováni na jednotlivce, které nemáme při sepisování př́běhu Karlova brát vážně. Autenticita vzpomínání souvisí s přítomností lidí, kteří jsou považováni za „starousedlíky“, členů vlastní věkové kategorie, nebo bezprostředních sousedů. Aby si „Karlováci“ takový autentický zážitek dopřáli, kromě veřejných srazů organizují i setkání pro užší, nejčastěji vrstevnické skupiny, které nejlépe navodí zážitek sousedského společenstva, na rozdíl od přítomnosti lidí, kteří se na Karlově nenarodili:

Ti se tam přivdali, nebyli Karlovský. A od té doby, co máme srazy pravejch Karlovskejch, tak na ně ani nechodí. (M. M.)

Já třeba ty lidi neznám ani podle jména, ale znám je podle vidění, protože jsem je potkávala celý roky. No a navíc mně jména obecně moc v paměti neutkvívají. Takže jako vím, bydleli třeba v sedmé ulici a tak, ale nevím, jak se jmenovali. Člověk ne všechny zná tak, že se s nimi baví, ale většinou... většinou si tam člověk vybere ty svoje vrstevníky. Takovou svoji skupinu a pak se tam sedí po těch partách po celém sále. (K. K.)

Organizátoři srazů připravili několik mnemotechnických pomůcek, jako jsou např́iklad schéma ulic se seznamem prŕjimení jednotlivých rodin, soubor fotografií nebo stručná „historie“" výstavby Karlova sepsaná na základě archivních dokumentů. To vše slouží jako pamět’ové pomůcky a používá se také pro potřeby vnější reprezentace, jako materiál do novinových článků. Organizátoři srazů si ale zároveň uvědomují, že vzpomínkový Karlov „přežije“ pouze v participativním vzpomínání, a proto usilují o získání nástupnické generace mladších „Karlovákư‘, která by srazy v budoucnu organizovala:

Chceme to předat, ne že bychom se toho vzdávali, ale chceme, aby to ty mladý dělali, aby chodili ty, co se tam na tom Karlově narodili, co tam vyrostli. Zatím jsme zapojili dva, tak bychom byli rádi, kdyby nám kluci pomohli, aby to žilo dál. (J. Z.) 


\section{Historizace a nostalgizace městských prostorů}

Postmoderní historizaci a nostalgizaci architektury a urbánního rozvoje lze chápat jako součást širších procesů „kreativní destrukce“12 pozdního kapitalismu a jeho socioprostorové reorganizace městského prostoru (Zukin 2001). Neoliberální logika transformuje průmyslovou městskou „krajinu výroby“ v post-industriální „krajinu spotřeby“ (Zukin 1991, 1998) a jejím revitalizačním sítem lze úspěšně protlačit pouze takové objekty, které v daných socioprostorových podmínkách umožňují rekonverzi pro „masovou spotřebu jídla, umění, módy, hudby a turismu“ (Dickinson 2001: 48). Plzeňský Útvar koncepce a rozvoje vydal k př́padu výše zmíněného pivovaru Světovar oficiální oznámení, v němž prezentoval svůj rozvojový záměr. Úřad vyzdvihoval atraktivitu dané lokality pro potenciální investory důrazem na průmyslovou minulost, původní funkci a architektonický ráz, ale i na budoucí možnosti pro aktivity masové kulturní spotřeby a - samožrejmě - socioprostorový charakter prostředí produkující autentickou atmosféru:

Světovar bývala značka piva, které se vařilo v pivovaru v jižní části Plzně. Původní areál je dnes obklopen živou obytnou čtvrtí Slovany a patří mezi významné rozvojové plochy v majetku města $(5,1$ ha). Plzeň vypsala na využití území v roce 2010 urbanisticko-architektonickou soutěž a následně vítěz zpracoval podrobnou studii, takže urbanisticky a kapacitně je území připraveno. Těžištěm areálu jsou historické památkově chráněné průmyslové budovy, které propůjčují místu jedinečnou atmosféru. V jedné z nich, budově stáčírny a ležáckých sklepů, vznikne do roku 2015 víceúčelová divadelní scéna 4x4 Cultural Factory a městský archiv. Na sousední budovu varny s kotelnou je zpracována studie využití pro Muzeum designu a životního stylu zřizované Uměleckoprůmyslovým muzeem v Praze. Území se tak přetváří na kulturní a společenské centrum a cílem je doplnit jej o funkce obchodní, kancelářské a obytné, aby se Světovar stal živým polyfunkčním centrem, kde historické budovy budou doplněny soudobou architekturou. (Útvar koncepce a rozvoje Plzeň 2013)

Jak upozorňují Richard Lloyd a Terry Nichols Clark (2001), v post-industriálním kontextu jsou pro oživení městské ekonomiky stále důležitější investice do míst masové kulturní spotřeby. Mezi nejdůležitější průmyslové sektory se dostává sektor zábavy, trávení volného času nebo turismu a projekty městského rozvoje se přizpůsobují čím dále tím zřetelnější poptávce středních a vyšších tříd po takových možnostech spotřebního vyžití, které by zvyšovaly „kvalitu“ jejich života v podobě sportovní, stravovací nebo poznávací spotřeby. Lloyd a Clark v této souvislosti hovoří o postindustriální „nové generaci občanư“, kteří - relativně zajištěni - ekonomicky nestrádají a hledají uspokojení nových identitárních, intelektuálních a estetických potřeb (tamtéž). Také rekonverze průmyslových objektů vyžaduje kulturní ospravedlnění (Zukin 1987). ${ }^{13}$ Podle Sharon Zukin (2009) vytvořila mediální reprezentace

12 Koncept „kreativní destrukce“ byl odvozen od Marxova postřehu, že proces akumulace bohatství v kapitalismu je neoddělitelně spojen s jeho „ničením“ v jiné fázi ekonomického cyklu (Marx [1858/1939] 1973).

13 Plzeň 2015 a město Plzeň dokonce podporují výzkumný projekt „Příběh Světovaru“, jehož cílem ,je zmapovat pamět' a genius loci areálu Světovar v kontextu celého obvodu Plzeň 2 - Slovany. Se zapojením místních pamětníků i pamět’ových a vzdělávacích institucí, zvědavců, objevitelů, badatelů a dalších hledáme a utváŕíme vzájemný vztah lokality, místní komunity a objektu Světovar. 
„dobrého města“ základ pro propojení kapitálu, státu a nové městské střední třídy. Výsledný obraz „dobrého autentického města“ vytvářený optikou kultury „dobrého spotřebitele“, který vyhovuje vkusu střední třídy a představám místních kulturních aktivistů, architektů a urbanistů, představuje tuto „autenticitu“ jako otázku estetizace, která nemá nic společného s mocenskými vztahy a s marginalizací těch, kteří se na budoucí tváři městské krajiny podílet z nejrůznějších důvodů nemohou (Zukin 2009: 551).

V daném kontextu revalorizace průmyslového dědictví a historizace urbánních prostor a architektury se může naše studie jevit na první pohled nepatřičně. Vpravdě, v popředí našeho zájmu nestojí snaha o záchranu a zachování objektů jako mist (urbánní) paměti (Nora 1998; Crinson 2005), ale naopak chceme studovat odpor vůči fixaci identity v rámci historického narativa městského prostoru.

Velké komplexy objektů, které v Evropě a severní Americe odkazují k průmyslové minulosti a které v dnešní době již ztratily svoji původní funkci, čeká několik možných osudů. Prvním ze čtyř takových př́padných osudů je dle Jamese Dickinsona (2001) demolice, devastace nebo taková degradace lokality, která bude bránit jejímu novému využití. Druhým pomyslným osudem může být opětovné použití průmyslových objektů pro potřeby nového ekonomického režimu, aniž by byla konzumována jejich historizovatelná hodnota. Třetí možností je transformace objektů $\mathrm{v}$ historické památníky a mista paměti. Př́padně mohou, začtvrté, přerůst $\mathrm{v}$ novodobé ruiny, $\mathrm{v}$ relikty připomínající ztracenou minulost (Dickinson 2001). Podobně jako Dickinsona, i nás v našem textu zajímá, ,jak se vyjednávají nové významy a hodnoty pro nedávno zastaralé, zchátralé a opuštěné utilitární struktury“ (Dickinson 2001: 34).

\section{Historizace a nostalgizace vzpomínkového Karlova: Válka, bombardování a Američani}

Dle Marka Crinsona (2005) dnešní vzpomínkový průmysl obzvlášt' oceňuje vzpomínání na kolektivní traumata $\mathrm{v}$ souvislosti s druhou světovou válkou, která $\mathrm{v}$ sobě vždy zahrnuje nenávratnou ztrátu. $\mathrm{V}$ našich rozhovorech $\mathrm{s}$ informátory ani v průběhu pozorování srazů jsme žádnou snahu o rutinizaci kolektivního traumatu války nezaznamenali. Pro Karlov muselo bombardování na úplném konci války znamenat obrovskou ránu, zničeny byly tři ulice i oslavovaná škola, „karlovská Sorbonna“. Členové společenstva paměti ale událost bombardování nevyužívají k začlenění do narativa paměti městské, potažmo státní. Vyprávění o rozsáhlém bombardování je pojímáno spíše jako dobrodružství a v průběhu srazů není př́iliš dramatizováno, $\mathrm{k}$ ritualizaci kolektivního traumatu nedochází.

Kombinujeme záznamy rozhovorů s pamětníky a studium dostupných historických dokumentů a archiválií. Chceme poukázat na výjimečnost místa, hledat odpovědi na otázky, zda má areál potenciál stát se kulturním centrem?““(Místní kultura 2013). Na rozdíl od vzpomínkového Karlova (viz níže) je nutné nejdříve vytvořit jak společenstvo pamětníků, tak reprezentační narativum. Dodáváme, že Světovar - postaven stejnou firmou zhruba ve stejné době jako Karlov - sloužil své původní funkci méně než dvacet let. 
Jednou jsme se pokoušeli zjistit, zda má zbytkový Karlov mnemotechnický potenciál pro mobilizaci kolektivního traumatu bombardování. Na srazu uspořádaném na místě bývalého Karlova (viz níže) jsme vybrané pamětníky oslovili s dotazem, zda by nám nešli ukázat, kde byly ony kryty - „zemljanky“. Ukázalo se, že je takový nápad nenadchnul a spíše než o devastujícím bombardování Karlova (Američany) by rádi mluvili o americkém osvobození Plzně. Když se podíváme na současný socioprostorový kontext a dominantní městské pamětnické narativum, tak lze takové reprezentační strategie vysvětlit jednoduše. Bombardování sice zasáhlo budovy, neznamenalo ale přerušení komunitního života na Karlově, jak je na něj dnes vzpomínáno. Zároveň toto bombardování není na městské úrovni ritualizovaně komemorováno, $\mathrm{k}$ těmto účelům neexistuje ani žádný adekvátní památník; důvodem je pravděpodobně skutečnost, že bombardování provedli hrdinové pamětnického narativa - Američané jako osvoboditelé Plzně. Samotná ztráta objektů/budov se nestala zdrojem ritualizované nostalgie i z toho důvodu, že byla překryta ztrátou dělnické kolonie jako takové, která v čase prvních organizovaných srazů v posledním roce před demolicí (1986) představovala onu neodmyslitelnou „př́tomnost neprítomnosti“ (presence of absence) bloků domů jako materiální základny pro život karlovského sousedského společenstva. Ačkoliv lze bombardování považovat za jeden z hlavních důvodů postupné degradace čtvrti, vedoucí $\mathrm{k}$ její konečné demolici, pro Karlováky nenese význam kolektivního traumatu. Historizaci a nostalgizaci umožňují pravidelná setkávání sloužící jako zpřítomnění zmizelého sousedského života a na dominantní městské pamětnické narativum se Karlováci napojují skrze sdílené vzpomínání na americké osvobození.

\section{Společenstvo vzpomínání a zapomínání: „Mami vždycky říkala, na Karlově kvetou i cihly"}

Jak ukazujeme na jiném místě (Burzová a kol. 2013), tak vzpomínání organizované společenstvem paměti je jako každé vzpomínání určitou interpretací minulosti. Zároveň totiž „,[u] dálosti, jež nenachází svůj referenční rámec v současnosti, upadají do zapomnění“ (Szaló a Hamar 2006: 122). Vzpomínkový Karlov nemůže existovat bez „událostí společného vzpomínání“ (tamtéž: 124). V souladu s výše uvedenou sdílenou reprezentací Karlova je nutné mít na paměti, že nejen historie, ale i vzpomínková minulost je vždy selektivní konstrukcí (RoseRedwood a kol. 2008).

Význam událostí společného vzpomínání, tedy pravidelných „karlováckých“ srazů, se ukazuje $\mathrm{v}$ rozhovorech $\mathrm{s}$ bývalými obyvateli Karlova, kteří se setkání z nejrůznějších důvodů neúčastní. Tito informátoři proti vzpomínkovému narativu „soudržných karlovských patriotů “ zdůrazňují, že mají na Karlov pouze mlhavé vzpomínky a necítí žádnou identifikaci se vzpomínkovým Karlovem prostě proto, že žijí „dneska úplně jinou realitou“ (P. R.).

Chátrání dělnické kolonie Karlov bylo završeno demolicí posledních stojících domů $\mathrm{v}$ roce 1986. Ačkoliv by se $\mathrm{v}$ logice postmoderního vzpomínání mohlo zdát, že demolice by ve sdílených reprezentacích mohla zaujmout roli kolektivního traumatu, pro naše informátory tuto roli nehraje. Většina $\mathrm{z}$ nich se totiž z Karlova dobrovolně odstěhovala o řadu let dříve za lepším bydlením a těch, kteří zůstali na Karlově takříkajíc „do konce“, byla 
oproti předchozím desetiletím jenom hrstka. ${ }^{14}$ Samotní organizátoři srazů a zmiňovaní „praví Karlováci“‘ jsou až na výjimky pamětníky, kteří na Karlově prožili mládí a následně se přestěhovali na jedno z nově zbudovaných plzeňských sídlišt'. Právě jejich společně vyjednávané a sdílené vzpomínky tvoří jádro dnešní oficiální sdílené reprezentace. Pokud pamětníkům ukazujeme fotografie pořízené krátce před demolicí v rámci výzkumů, které na Karlově realizovalo tehdejší Oddělení etnografie dělnictva při Etnologickém ústavě ČSAV, dostává se nám jednoznačných reakcí, že už se nejedná o Karlov. Skutečný vzpomínkový Karlov konstituuje zcela odlišná obraznost:

To tam bylo všechno - potraviny a hospody, tělocvičny pro děti... Tam bylo všechno. Naše mami vždycky ř́kala „na Karlově kvetou i cihly“, a skutečně, dvorky byly vyložený cihlami a mezi nimi rostly pomněnky. Tak proto mami říkala ,já z Karlova nepůjdu, tady kvetou i cihly“. (M. M.)

Za součást zbytkového Karlova lze tudíž považovat i soubor fotografií, kterým pamětníci nepřiznávají mnemonickou funkci. Ukazuje se, že dodnes viditelné plochy, které přetrvaly demolici dělnické kolonie, stejně jako i zbytek stromů, parčík, Lidový dům a sokolovna, neplní nostalgizační funkci výše zmíněné „,přítomnosti nepřítomnosti“ (presence of absence), tedy bezprostřední zažívání ztráty minulého. Jsou spíše součástí „přítomnosti přítomnosti“ (presence of presence), tedy bezprostředního uvědomování si přítomnosti nežádoucích jevů, které by pamětníky a jejich vzpomínkový Karlov - kdyby se s daným (ne)místem participativně ztotožňovali - mohly stigmatizovat.

\section{Problematický status zbytkového Karlova}

V našem výzkumu se kromě vzpomínkového Karlova zajímáme také o Karlov zbytkový: o jeho současnou transformaci a budoucnost jako jednoho z reliktů plzeňské průmyslové minulosti (Crinson a Tyrer 2005: 49-50). Zbytkový Karlov je souborem pozůstatků průmyslové expanze Plzně, který podléhá degradaci a procesu postupného zapomnění. Jak jsme již uvedli, komemorativní rozhodování vždy podléhají socioprostorovým podmínkám. Proto se ptáme po důvodech toho, že Světovar - u kterého je nutné propojení s městskou pamětí a sousedskou komunitou teprve utvářet - může být privilegovanou zónou kulturního dědictví a vhodným zázemím pro umístění průmyslové paměti, zatímco zbytkový Karlov se jím - přes existenci aktivního společenstva paměti, idealizovaného pamětnického narativa a soulad s městským pamětnickým narativem - pravděpodobně nestane. Strukturální omezení se ukáže ve chvíli, kdy do dané lokality vstoupíme společně s někdejším obyvatelem a pokusíme se představit si, jak by se zbytkový Karlov mohl použít jako rámec pro „vidění, poznání a porozumění světu“. Materiálním ztělesněním strukturálního omezení je městská krajina dostupná oku pozorovatele, který se nachází prrímo v lokalitě. Krajina odkazuje jak k „materiální topografii“" toho, co lze vidět, tak ke ,způsobu pohledu“ na ni (Creswell 2004: 10). Krajina je něco, co nemůžeme ovlivnit, protože stojíme vždy mimo ni.

14 Dle statistického lexikonu obcí ČSSR žilo na Karlově v roce 19611277 osob, v roce 1970968 osob a v roce 1982 už jenom 262 osob (Lexikon 1984). 
Obrázek 2: Karlov krátce před demolicí v roce 1986

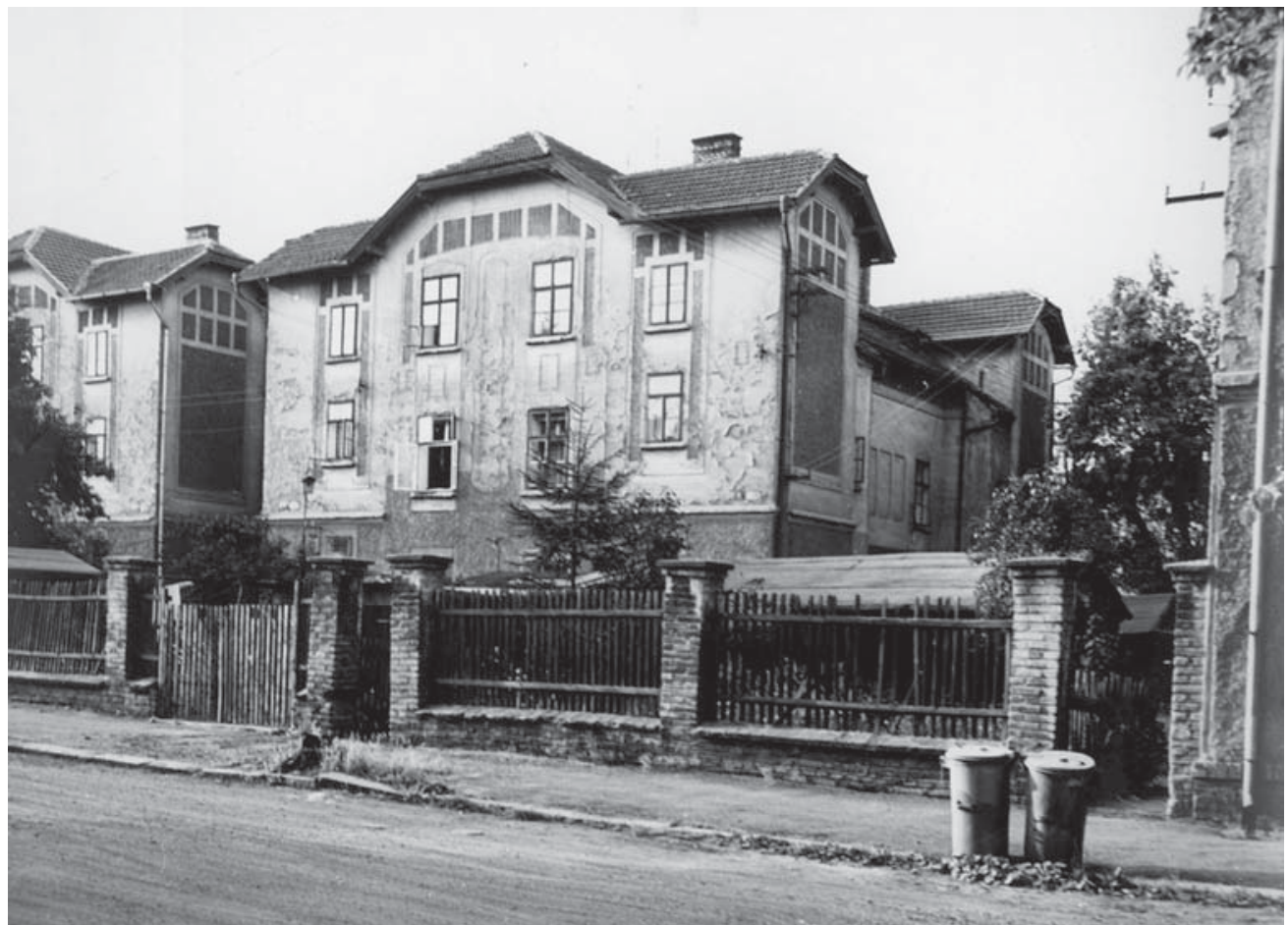

Zdroj: Archiv Západočeského muzea v Plzni

Abychom se lépe dokázali vžít do představ a pocitů pamětníků, pokusme se porovnat, jak vidí někdejší obyvatelka (M. R.) okolní prostor a krajinu v minulosti a jak na okolí zbytkového Karlova nahlíží dnes.

Někdejši Karlov:

Můj otec bydlel na Karlově ještě před válkou a říkal, že před válkou to tam bylo nádherný, že to bylo jako zahradní čtvrt'. V ulicích to bylo velmi hezký, protože v nich stály kaštany, samé velké vzrostlé kaštany. Ty byly v ulicích po obou stranách domů. A dole jak vedla hlavní ulice, tak tam byly zase samé lípy. V okolí Karlova bylo samé pole a louky. A také zahrady. Zahrádky jsme měli před tím parčíkem a ty se táhly až dozadu k letišti. $Z$ jedné strany samé pole, $\mathrm{z}$ druhé zahrádky a zezadu to bylo zase jen Škodovka.

\section{Zbytkový Karlov:}

Informátor: My si na ten dnešní Karlov akorát vzpomeneme, když jedeme okolo. To si tak říkáme „hele tady byl Karlov“. Ted’ je tam akorát plac, na kterém jsou tam auta. Není tam vůbec nic, co by vám prostě Karlov připomínalo.

Tazatel: Myslíte, že je to dobře, že tam není nic, co by tam připomínalo tu kolonii? 
Informátor: No zatím tam stojí akorát tak sokolovna a ten Lid’ák. Už si to nějak nepřipouštíte, protože [smích] život běží dál a pořád se něco bourá, staví, takže ono už vám to pak ani tak nějak nepřijde.

\section{Místa komemorace: Éčko a sokolovna}

Součástí našeho výzkumu bylo polozúčastněné pozorování událostí pamětnických srazů a dalších vzpomínkových obřadů Karlováků. Protože jsme chtěli lépe pochopit organizaci srazů, zapojili jsme se do př́ípravných aktivit dvou z nich. Zajímalo nás, co všechno organizace obnáší, jaká jsou očekávání účastníků srazů a podmínky jejich naplnění a také případné problémy, které srazy obnáší. První sraz se konal v restauraci Éčko nacházející se v moderním multifunkčním centru v poklidné části plzeňské čtvrti Slovany. V této restauraci se srazy konají opakovaně již několik let a zdá se, že Karlovákům se reprezentativní prostory líbí. Od počátku výzkumu nás zajímalo, proč se srazy nekonají přímo v karlovské sokolovně, kde by to možné bylo. V tomto objektu kromě tělovýchovné jednoty sídlí fungující restaurace, v prostorech bývalé tělocvičny se konají také diskotéky a koncerty (Rokáč Karlov). Když jsme tento objekt s organizátory navštívili, rozhodli se, že další sraz tam uspořádají.

Obrázek 3: Místa komemorace hrají významnou roli v proměnách geografie vzpomínání a zapomínání. Současným místem komemorace „Karlováků“ je restaurace v suterénu moderní budovy v klidné čtvrti prostorově i symbolicky vzdálené někdejšímu Karlovu

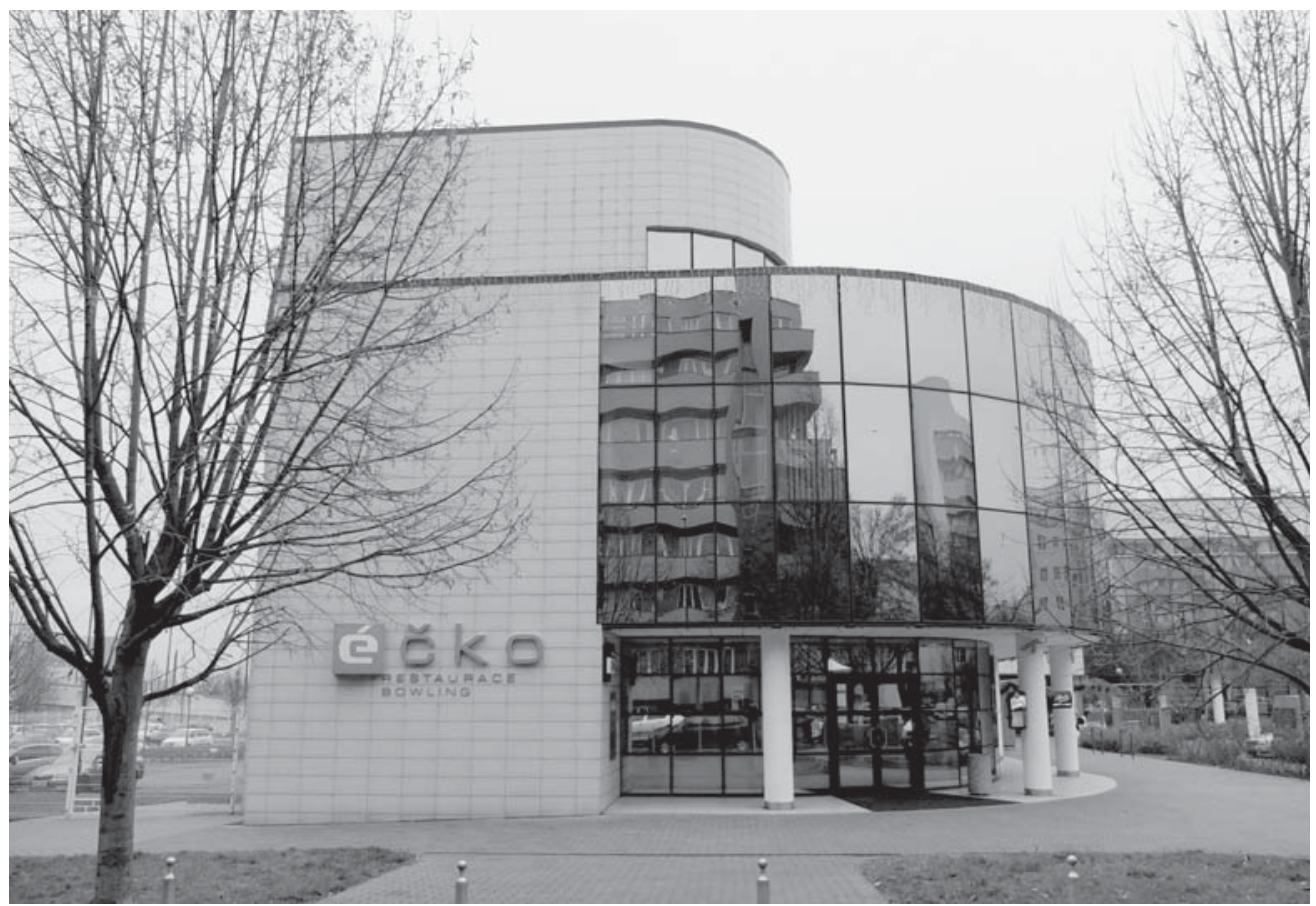

Zdroj: Autoři 
Obrázek 4: Bývalá karlovská sokolovna ve stigmatizovaném prostředí městských marginálů sloužící jako restaurace, diskotéka. Vedle a naproti se nacházejí ubytovny, z druhé strany parkoviště pro kamiony

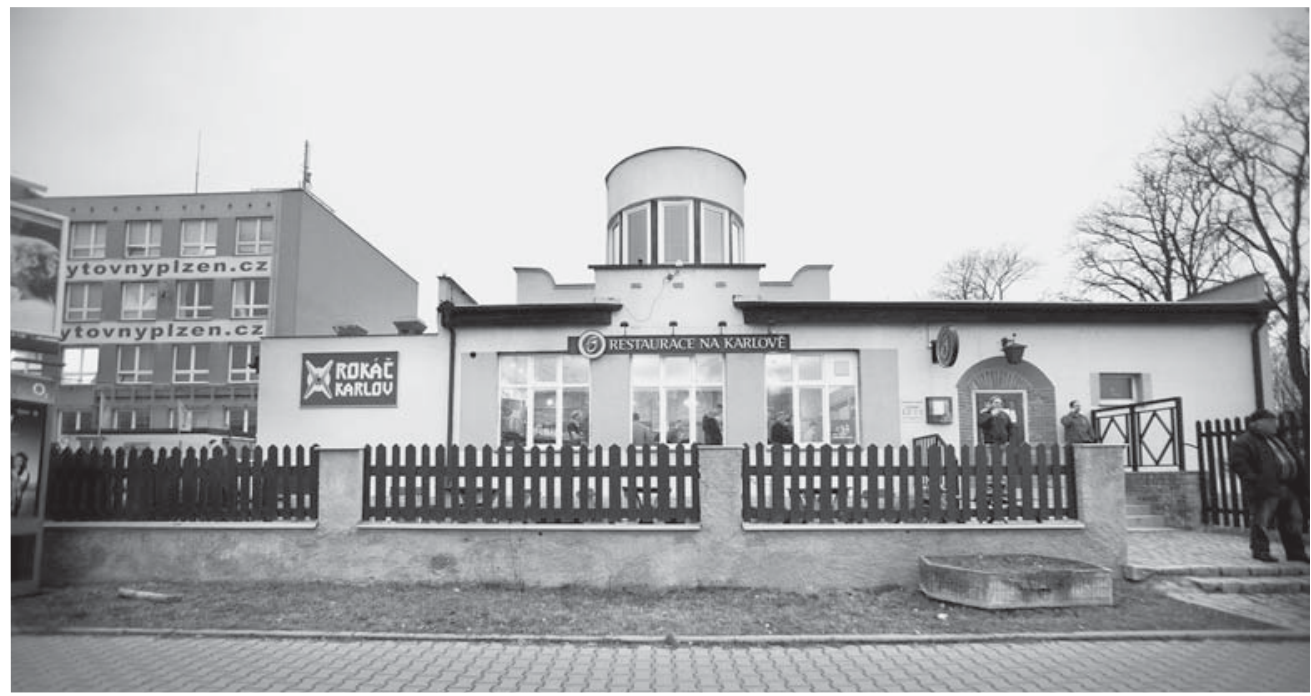

Zdroj: Autoři

Očekávali jsme, že místo zbytkového Karlova v informátorech vyvolá celou řadu vzpomínek. Objekt bývalého Lidového domu v dané chvíli patřil soukromé firmě v likvidaci a byl uzavřený. Oslovili jsme konkurzního správce v přesvědčení, že „Karlováci“ budou mít zájem o jeho návštěvu. Mimo jiné jsme také připravili fototechniku pro účely pořizování portrétů s reziduálním Karlovem pro případné potřeby pamětníků. Po zpětné reflexi jsme si uvědomili, že jsme očekávali, že dané místo vyvolá vlnu nostalgického vzpomínání a snad i oživí vztah Karlováků k reziduálním objektům. Napadalo nás mnoho možností, jak dané objekty využít, at' už dočasně (například pro zorganizování výstavy), nebo trvale (např́íklad pro instalaci památníku).

Průběh srazu nás překvapil. Od samého začátku bylo cítit, že účastníci srazu se v sokolovně necítí dobře. Nejenže nikdo neprojevil o procházku zbytkovým Karlovem ani minimální zájem; v průběhu večera nám bylo sdělováno, že ,je strašný, co s tím udělali“ (referujíc na prostor tělocvičny se stěnou pomalovanou v duchu vesmírné oblohy pro potřeby diskotéky). Když se hlavní organizátor srazu otevřeně zeptal, jestli se má příští sraz konat opět v sokolovně, nebo v původním Éčku, zaznělo téměř jednohlasné, poněkud znechucené „V Éčku!“‘. Uvědomili jsme si, že jsme podcenili komplexitu vztahu mezi pamětí a místem (Jones 2005: 208-209): že jsme něco důležitého pomyslně přehlédli a nereflexivně se snažili „Karlováky“ vměstnat do našeho vlastního pocitu nostalgie, který však souvisel s naší vlastní zakotveností ve zcela odlišném sociálním, historickém a biografickém kontextu. Karlováci se na (zbytkový) Karlov vrátit nehodlají, nebot' (vzpomínkový) Karlov je umístěn jinde a ve zcela jiné podobě. 
Obrázek 5: Pozůstatky Karlova překryje dle posledních zpráv nové depo pro Dopravní podniky. Naobrázku je vizualizace nového depa s poslední z Karlovských ulic Na pomezí.

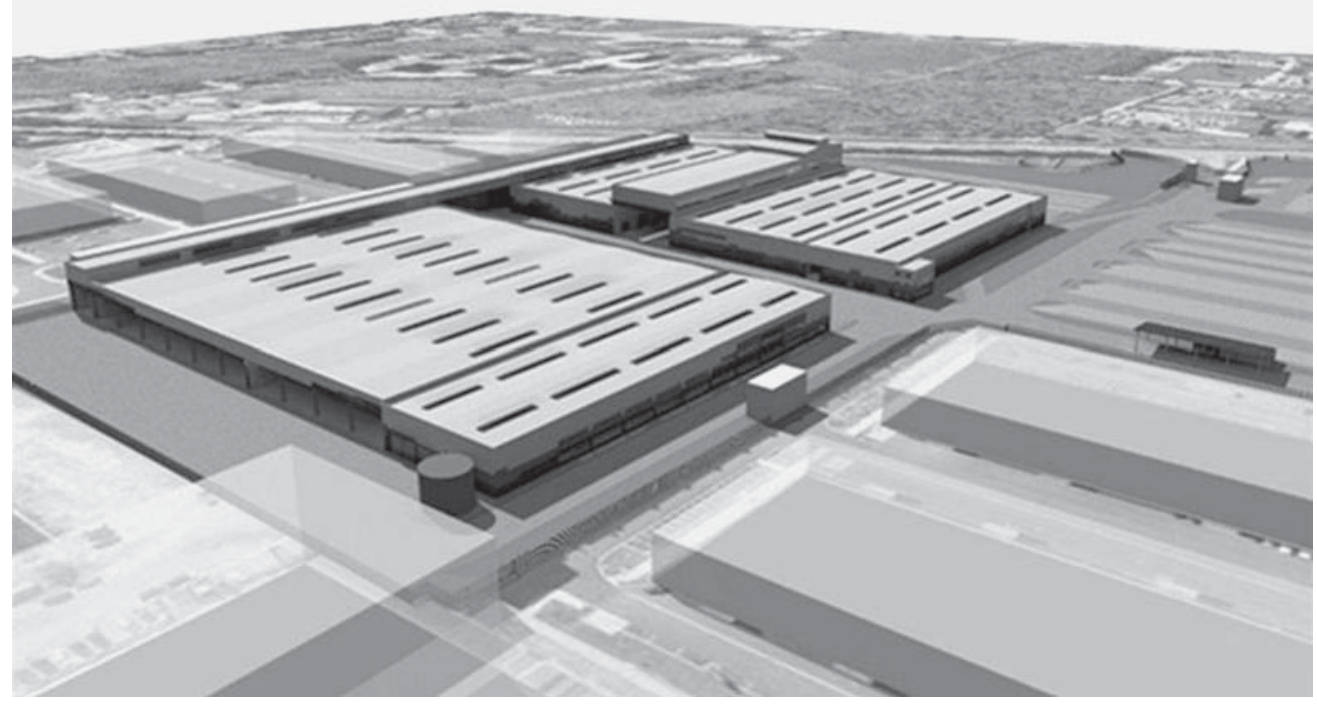

Zdroj: CIAS Holding a.s.

\section{Závěrem}

V předkládaném textu jsme se pokusili nastínit reprezentační strategie Karlováků v souvislosti se dvěma Karlovy. Prvním z nich je Karlov vzpomínkový, kterým je na pravidelných srazech organizovaná sdílená reprezentace bývalé dělnické kolonie, po které „,nic nezůstalo“. Druhým Karlovem pak je Karlov zbytkový aneb soubor reziduálních stop po někdejší dělnické kolonii, nyní reprezentovaný zejména objekty Lidového domu a sokolovny, kouskem bývalého parku a zbytkem ulic s několika stromy. V textu jsme, s odkazem na Dickinsona (2001), zmínili čtyři možné podoby budoucnosti pro pozůstatky průmyslové minulosti: demolici, opětovné využití pro komerční účely, transformaci v místa paměti a budoucnost v podobě novodobých městských ruin. Ačkoliv je (vzpomínkový) Karlov umístěn do symbolických míst paměti, jakými jsou oficiální narativum nebo soubor fotografií, reziduální Karlov zřejmě nečeká budoucnost materiálního a funkčního místa paměti. Nejspíš bude v blízké budoucnosti využíván pro komerční účely, a to bez mobilizace a realizace svého historizujícího a nostalgizujícího potenciálu. Rozhodli jsme se tuto budoucnost problematizovat. Zajímalo nás, co způsobuje přesvědčení Karlováků, že na místě zbytkového Karlova není „vůbec nic, co by vám... [vzpomínkový] Karlov připomínalo“ (M. R.), a to v kontextu, kdy dochází k výrazné revalorizaci průmyslových míst paměti. Tento trend organizátoři srazů reflektují, pravidelně „Karlovácké srazy“ zviditelňují v médiích, dokonce uvažují o založení sdružení.

Vrátíme-li se k Halbwachsově tezi, že kolektivní pamět’ trvá pouze po dobu trvání materiálního uspořádání, ke kterému se váže (2009: 185-227), tak by býval měl být zánik fyzického Karlova počátkem konce skupinového vzpomínání na Karlov. Jelikož k tomu v př́padě 
společenstva vzpomínání na Karlov nedošlo, navrhujeme Halbwachsovu tezi reinterpretovat. Závisí-li kolektivní pamět’ na „trvalosti“ prostoru, je pouze logické, že účastníci skupinového vzpomínání - dnes většinou již v seniorském věku - ztotožňují Karlov s jakousi ideální představou místa identity, které nebude mít vztah k dnešnímu prostorovému uspořádání. Právě ve vzpomínkovém Karlovu se totiž může uchovávat a reprodukovat jeho pomyslná neměnnost (Halbwachs 2009: 187), zatímco materiální změny a měnící se významy reziduálních objektů by měly pro kolektivní pamět' nedozírné následky. Pro kolektivní vzpomínání a jeho udržitelnost tedy není důležitý existující materiální prostor, a Halbwachsův text toto čtení připouští, nýbrž vitální a reprodukovatelná prostorová představa, která dává lidem dojem neměnnosti. Pokud Karlováci říkají, že Karlov již není, tak je tomu tak proto, že přistupují na nové významy, které jsou zbytkovým objektům a okolní krajině v dnešním městském diskurzu připisovány; jediným způsobem, jak uchránit pocit trvalosti kolektivní paměti, je Karlov přeznačit a zcela vymístit z městského prostoru do sdílené sféry představ.

Eviatar Zerubavel (1996) zdůraznil, že je nutné věnovat pozornost sociálnímu kontextu, do kterého je vzpomínání v té které době situováno. Způsob, jakým si něco pamatujeme, je vždy redukující interpretací podléhající překladu do jazyka specifických sociálních podmínek. Vzpomínkový Karlov se tak umist’uje „na pomezí“ mnemonické socializace karlováckých srazů a mnemonické tradice urbánní paměti podle pravidel vzpomínání a v socioprostorovém řádu pozdního kapitalismu. Toto pomezí svým umístěním do stigmatizované lokality, reprezentované jako „nic“, prostor, kde jsou jenom „ty ubytovny“, zabraňuje „Karlovákům“ použít reziduální Karlov jako materiální a funkční místo paměti. Pokud je místo zároveň způsobem, kterým rozumíme světu, tak je zřejmé, že Karlováci chtějí na svět nahlížet přes Karlov vzpomínkový. Pouze tento Karlov jim totiž umožňuje reprodukci obrazu určitého sociálního pořádku a představy o zdravém a správném městském životě, respektive o zdravém a správném Karlově. Karlováci si dobře uvědomují, že reziduální Karlov, to jsou objekty umístěné v krajině, která nevyhovuje postmoderním estetizujícím podmínkám „kvalitního způsobu života“. Jinak řečeno, na Karlov by - na rozdíl od Světovaru - dnes ,nikdo nechodil“; pouze „kamionisti“ nebo „ukrajinští dělníci“, ale také bezdomovci obývající nedaleké opuštěné zahrádky, tedy městští marginálové, kteří jsou z tvorby smysluplných míst v urbánní paměti zcela vyloučeni. Zbytkový Karlov, než jej nadobro překryje stavba nového depa Plzeňských městských dopravních podniků, si pravděpodobně ve sdílených reprezentacích a v myslích Karlováků a urbanistických aktivistů zachová ráz nebezpečného - nebo zbytečného - místa, jehož prostorové významy určuje politicko-ekonomická správa pozdního kapitalismu. Je příznačné, že zbytkový Karlov coby „smysluplné“ místo ještě reprodukuje městská policie:

V části Karlov a Borská Pole je činnost zaměřena na problematiku ubytoven, kde jsou ubytováni většinou cizí státní prříslušníci, někteří z nich v okolí páchají trestnou činnost a přestupky proti veřejnému pořádku. (Městská policie Plzeň 2013)

Obrat'me nyní alespoň krátce pozornost na zbytkový Karlov. Zdá se, že současný diskurz o zbytkovém Karlovu je natolik účinný, že nutí Karlováky kdysi privilegované místo přeznačit a vzdát se možnosti učinit z reziduí pamětní místo, a to bez ohledu na probíhající módní vlnu historizace a nostalgizace architektury. Je-li urbánní pamět' natolik selektivní, že podporuje pouze esteticky přijatelné památníky (pouze památníky, které jsou v dnešní urbánní 
paměti prezentovatelné jako atraktivní), můžeme sledovat dopad, jaký má tato významová marginalizace na identitu dnešních obyvatel zbytkového Karlova.

Dle Sharon Zukin představuje ekonomická krize a pozastavení megalomanských projektů městského rozvoje vhodnou „chvíli pro prozkoumání nedávných změn jak zastavěného prostředí měst, tak viditelných a neviditelných sil, které dnes ovlivňují měnící se městskou zkušenost“ (Zukin 2009: 543). Badatelé musí obrátit pozornost na rizika čistě estetizujícího hledání autentičnosti míst vhodných pro spotřební kulturu střední třídy, ze které často vycházejí jak kulturní aktivisté, tak oni sami. Dominantní diskurz selektivní urbánní paměti nesmí upozad'ovat či ,,poškozovat“ nízkopříjmové nebo marginalizované skupiny a kultury, které spoluutváří „městskou diverzitu“ (Zukin 2009: 544). Uvědomujeme si, že i my se musíme mít na pozoru a nepodlehnout ekonomické logice estetizující urbánní paměti připouštějící pouze určité reprezentace, které v plzeňské politice paměti v současnosti dominují. Proto jsme se v předloženém textu zamýšleli nad tím, proč se zbytkový Karlov nemůže zapojit do módní vlny historizace a nostalgizace průmyslových reliktů. Další otázkou, kterou bychom si chtěli v budoucnu položit, je, jak reprezentují zbytkový Karlov jeho dnešní obyvatelé a uživatelé, a co pro ně Karlov znamená, respektive v daném socioprostorovém řádu znamenat (ne) může? Kdo má dnes na Karlov nárok?

\section{Literatura}

BURZOVÁ, Petra L., Ilona DVOŘÁKOVÁ, Ondřej HEJNAL, Michal RŮŽIČKA a Laco TOUŠEK. Dělnická kolonie Karlov: Místo, pamět’ a identita. Český lid, 2013, roč. 100, č. 3, s. 259-279. ISSN 0009-0794.

CASEY, Edward S. Remembering: A phenomenological study. Bloomington (IN): Indiana University Press, 2000. ISBN 0253204097.

CRESSWELL, Tim. Place: A short introduction. Oxford: Blackwell, 2004. ISBN 1405106727.

CRINSON, Mark (ed.). Urban memory: history and amnesia in the modern city. New York: Routledge, 2005. ISBN 0415334063.

CRINSON, Marc a Paul TYRER. Clocking off in Ancoats: Time and remembrance in the post-industrial city. In CRINSON, Marc (ed.). Urban Memory: History and Amnesia in the Modern City. New York: Routledge, 2005, s. 49-74. ISBN 0415334063.

DICKINSON, James. Monuments of Tomorrow: Industrial Ruins at the Millennium. In GOTHAM, Kevin Fox (ed). Critical Perspectives on Urban Redevelopment. Amsterdam: Emerald Group Publishing Limited, 2001, s. 33-74. ISBN 076230541X.

FRAGNER, Benjamin. Konverze industriálních staveb jako prostředek generování nových urbanistických aktivit a otazníků. Zprávy památkové péče, 2004, č. 4, s. 284-288. ISSN 1210-5538 596.

GIBAS, Petr. Industrial Nostalgia: The Case of Poldi Kladno. Lidé města, 2008, roč. 10, č. 2, s. 92-114. ISSN 1212-8112.

HÁJEK, Tomáš. K tématu využití a transformací památkově hodnotné architektury. Architektúra \& Urbanizmus, 2009, č. 3-4, s. 144-157. ISSN 1212-4168.

HALBWACHS, Maurice. Kolektivní pamět’. Praha: Sociologické nakladatelství, 2009. ISBN 978-807419-016-2.

HARVEY, David. Justice, nature and the politics of difference. Malden (MA): B1ackwell, 1996. ISBN 978-1-55786-681-3. 
HARVEY, David. Spaces of hope. Berkeley: University of California Press, 2000. ISBN 9780520225787. JONES, Owain. An Ecology of Emotion, Memory, Self and Landscape. In DAVIDSON, Joyce, Liz BONDI a Mick SMITH (eds.). Emotional geographies. Aldershot: Ashgate, 2005, s. 205-218. ISBN 0754680126.

KOLEJKA, Jaromír a Martin KLIMÁNEK. Vymezení a typologie postindustriální krajiny Česka. Geografie. Sbornik České geografické společnosti, 2012, roč. 117, č. 3, s. 289-307. ISSN 1212-0014.

LLOYD, Richard a Terry Nichols CLARK. The city as an entertainment machine. In GOTHAM, Kevin Fox (ed). Critical Perspectives on Urban Redevelopment. Amsterdam: Emerald Group Publishing Limited, 2001, s. 357-78. ISBN 076230541X.

MARX, Karl. Grundrisse: Introduction to the Critique of Political Economy. Baltimore: Penguin Books, [1858/1939] 1973. ISBN 0140216677.

MĚSTSKÁ POLICIE PLZEŇ. Služebna Bory [online]. (C2013 [cit. 28. 5. 2013]. Dostupné z: http://www. mpplzen.cz/o-mestske-policii-plzen/sluzebny/bory/sluzebna-bory.aspx.

MÍSTNí KULTURA. Př́běh Světovaru [online]. C2013 [cit. 26. 5. 2013]. Dostupné z: http://www. mistnikultura.cz/pribeh-svetovaru.

NORA, Pierre. Mezi pamětí a historií: Problematika míst. Cahiers du CEFRES, 1998, č. 13, s. 7-31. ISSN 1805-0336.

NORA, Pierre. The reasons for the current upsurge in memory. Transit-Europäische Revue [online], 2002, č. 22 [cit. 26. 5. 2013]. Dostupné z http://archiv.iwm.at/index.php?option=com_content\& task= $=$ iew\&id=285\&Itemid=463.

OLICK, Jeffrey K., Vered VINITZKY-SEROUSSI a Daniel LEVY (eds.). The collective memory reader. Oxford: Oxford University Press, 2011. ISBN 0195337425.

ROSE-REDWOOD, Reuben, Derek ALDERMAN a Maoz AZARYAHU. Collective memory and the politics of urban space: an introduction. GeoJournal, 2008, roč. 73, č. 3, s. 161-164. ISSN 1572-9893.

SZALÓ, Csaba a Eleanóra HAMAR. Váš Trianon, náš holocaust: segregace a inkluze kultur vzpomínání. In MARADA, Radim (ed.). Etnická různost a občanská jednota. Brno: Centrum pro studium demokracie a kultury, 2006, s. 117-142. ISBN 80-7325-111-6.

SZALÓ, Csaba a Radim MARADA. Vzpomínání a pamět'. Sociální studia, 2010, č. 1, s. 7-8. ISSN 1214-813X.

TEMELOVÁ, Jana a Jakub NOVÁK. Z průmyslové čtvrti na moderní městské centrum: proměny ve fyzickém a funkčním prostředí centrálního Smíchova. Geografie. Sborník České geografické společnosti, 2007, roč. 112, č. 3, s. 79-97. ISSN 212-0014.

TRUC, Gérôme. Memory of places and places of memory: for a Halbwachsian socio-ethnography of collective memory. International Social Science Journal, 2011, roč. 62, č. 203/204, s. 147-159. ISSN 1468-2451.

ÚTVAR KONCEPCE A ROZVOJE PLZEŇ. Světovar [online]. C2013 [cit. 28. 5. 2013]. Dostupné z: http://www.bvv.cz/urbis-invest/urbis-invest-2013/aktuality/svetovar.

ZERUBAVEL, Eviatar. Social memories: Steps to a sociology of the past. Qualitative Sociology, 1996, roč. 19, č. 3, s. 283-299. ISSN 1573-7837.

ZUKIN, Sharon. Gentrification: culture and capital in the urban core. Annual Review of Sociology, 1987, roč. 13, s. 129-147. ISSN 0360-0572.

ZUKIN, Sharon. Landscapes of Power: From Detroit to Disneyland. Berkeley: California University Press, 1991. ISBN 9780520082885.

ZUKIN, Sharon. Urban lifestyles: diversity and standardisation in spaces of consumption. Urban Studies, 1998, roč. 35, č. 5/6, s. 825-839. ISSN 0042-0980.

ZUKIN, Sharon. How to create a culture capital: reflections on urban markets and places. In BLAZWICK, Iwona (ed.). Century city: Art and culture in the modern metropolis. London: Tate Gallery Publishing, 2001, s. 258-265. ISBN 1854373447. 
ZUKIN, Sharon. Naked city: The death and life of authentic urban places. Oxford: Oxford University Press, 2009. ISBN 0199794464.

\section{Autoři}

Autorský tým je tvořen sociálními/kulturními antropology a sociology, kteří se věnují širokému spektru témat z oblasti studia městských společností, jako jsou problematika chudoby a marginalizace, konstrukce sociálních identit a vyjednávání skupinových hranic či sociální produkce a sociální kontrola urbánního prostoru. Ve svém současném kolektivním historickém a etnografickém výzkumu se zabývají studiem zaniklé dělnické kolonie Karlov v Plzni. Kontakt: info@plzenskykarlov.cz 